\title{
28 Resarch Square \\ CCR2 Contributes to the Homing of MSCs and Liver Regeneration
}

\section{Research Article}

Keywords:

Posted Date: August 26th, 2021

DOl: https://doi.org/10.21203/rs.3.rs-744956/v2

License: (c) (1) This work is licensed under a Creative Commons Attribution 4.0 International License.

Read Full License 


\section{Abstract}

The full text of this preprint has been withdrawn by the authors due to author disagreement with the posting of the preprint. Therefore, the authors do not wish this work to be cited as a reference. Questions should be directed to the corresponding author.

\section{Full Text}

The authors have withdrawn this preprint from Research Square. 